\author{
Marijana M. Prodanović* \\ Univerzitet Singidunum \\ Poslovni fakultet u Beogradu \\ SP Anglistika
}

Valentina M. Gavranović**

Univerzitet Singidunum

Poslovni fakultet u Beogradu

SP Anglistika

\title{
RAZVIJANJE JEZIČKIH VEŠTINA U ONLAJN NASTAVNOM OKRUŽENJU NASTALOM USLED ŠIRENJA VIRUSA KOVID-19 - DOMETI I OGRANIČENJA
}

\author{
Originalni naučni rad \\ UDC 004.738.5:378.147.31/.34 \\ $371.3:: 81^{\prime} 243$ \\ https://doi.org/10.18485/kkonline.2021.12.12.13
}

Izbijanje pandemije prouzrokovane širenjem virusa Kovid-19 ostavilo je značajnog traga na obrazovne sisteme širom sveta koji su se suočili sa brojnim preprekama i izazovima u organizovanju nastavnog procesa, čiji integralni segment čini i oblast podučavanja jezika. Ovaj rad predstavlja pilot studiju i za cilj ima da ispita afektivne stavove studenata anglistike prema realizaciji nastave jezika u onlajn okruženju, kao i mogućnostima za razvijanje svih jezičkih veština u datom nastavnom kontekstu. Istraživanje obuhvata analizu rezultata ankete zasnovanoj na Likertovoj skali procene, koja ispituje stavove studenata prema različitim aspektima učenja i podučavanja jezika u onlajn okruženju, kao i korelaciju odgovora koji se odnose na afektivne stavove prema svakodnevnoj komunikaciji u onlajn okruženju i komunikaciji tokom onlajn nastave, a potom i korelaciju jezičkih veština. Rezultati istraživanja predstavljeni su kvalitativno, narativnim opisom i komparacijom kategorijalnih varijabli, ali i kvantitativno, statističkim prikazom rezultata za svako pitanje iz ankete. Rezultati istraživanja ukazuju na visok stepen pozitivnog odnosa studenata prema svim aspektima podučavanja jezika u onlajn okruženju, ali i na korelacije koje postoje između stavova prema mogućnostima razvijanja produktivnih i receptivnih veština.

Ključne reči: onlajn nastava, razvijanje jezičkih veština, stavovi studenata anglistike

\section{Uvod}

Pandemija virusa Kovid-19, koja je obeležila početak 2020. godine, dovela je do promena neslućenih razmera u svakodnevnim životima ljudi širom sveta. Nastavni proces, prepun izazova per se, postao je još složeniji u trenucima kada je pomenuta pandemija zaključala učionice širom sveta, i nastavnike i učenike stavila u do tada

\begin{tabular}{lllllll}
\hline * Poslovni fakultet u $\mathrm{u}$ Beogradu, & Danijelova & 32, & 11000 & Beograd, & Srbija; & e-mail: \\
mprodanovic@singidunum.ac.rs & & & & & &
\end{tabular}


nepoznatu situaciju, u kojoj je, gotovo preko noći, bilo potrebno korenito promeniti dotadašnje navike, pristupe, kao i metode, sredstva i nastavne materijale.

UNESCO je, tokom meseca aprila 2020. godine, potvrdio da je 1.575.270.054 učenika (u širem smislu) doživelo preokret u procesu obrazovanja (Huang et al., 2020, str. 97). Administracije širom sveta, zajedno sa obrazovnim institucijama i svim učesnicima nastavnog procesa, reagovale su na nove zahteve promptno, nastojeći da započete aktivnosti, koliko god je to moguće, završe onako kako je prvobitno bilo planirano. Celokupan nastavni proces, na svim obrazovnim nivoima, nastavio je da se odvija u novom, onlajn okruženju.

Uvođenje digitalizacije u nastavne procese na svim nivoima, jedna je od vodećih preporuka EU dokumenata koji se odnose na politiku obrazovanja; digitalizacija, i pre same pandemije, nije bila nepoznanica, te nastavnici, idući u korak sa savremenim tokovima, poslednjih godina, u svojim svakodnevnim aktivnostima, sve više primenjuju digitalna sredstva. Ipak, iako su prednosti uključivanja digitalnog u obrazovanje nebrojene, i dalje je prisutan nemali broj ograničenja koja predstavljaju izazov za njegovu uspešnu primenu.

Iako podučavanje uz pomoć savremenih tehnologija i upotrebe različitih obrazovnih platformi, kako smo ranije nagovestili, ne predstavljaju novinu u politikama obrazovnih institucija i ustanova, značaj koji učenje na daljinu dobija u novonastalim okolnostima nikada nije bio tako izražen. Takođe, izazovi održavanja nastave u onlajn okruženju postali su vidjiviji no ikada - tehnička opremljenost, prilagođenost postojećih nastavnih planova i programa digitnalnom modelu instrukcije, obučenost nastavnika, motivisanost učenika - samo su neka od pitanja sa kojima se svakodnevno susreću nastavnici i učenici sa različitih meridijana i na različitim nivoima obrazovanja.

Ovaj rad ima za cilj da istraži stavove studenata anglistike u vezi sa učenjem jezika i jezičkih veštima u onlajn nastavnom okruženju. Pored ispitivanja stavova studenata, u ovoj pilot studiji ćemo se baviti i korelacijom odgovora koji se odnose na afektivne stavove prema svakodnevnoj komunikaciji u onlajn okruženju i komunikaciji tokom onlajn nastave, kao i korelacijom koja se uspostavlja između statova studenata prema mogućnostima razvijanja receptivnih i produktivnih jezičkih veština.

\section{Novonastale okolnosti obrazovanja u Kovid eri}

Pružajući potporu nastavnicima i učenicima širom sveta, u procesu svojevrsne tranzicije obrazovanja, UNESCO je stvorio Svetsku obrazovnu koaliciju (eng. Global 
Education Coalition) ${ }^{3}$, dok je Evropska komisija pokrenula niz aktivnosti u vezi sa sprovođenjem Akcionog plana digitalnog obrazovanja (eng. Digital Education Action Plan), u cilju, ne samo osvetljavanja fenomena, već i lakše i uspešnije primene svih tehničkih mogućnosti u ovoj oblasti ${ }^{4}$, koja zahteva pažljivo i svesno planiranje aktivnosti. ${ }^{5}$

Premda se, kako nastavnici, tako i učenici širom sveta, još uvek privikavaju na izmenjeni kontekst obrazovanja, OECD, u svom izveštaju koji ilustruje stavove ispitanika iz 98 zemalja sveta, ukazuje na učestala pitanja koja navedeni akteri obrazovnog procesa postavljaju odnosno na koja odgovaraju; čini se da, sudeći po rezultatima predstavljenim u izveštaju, bojazan i dalje postoji u vezi sa pitanjima kao što su: kompletiranje ciklusa učenja (diplomiranje), evaluacija, kontinuitet, tehnička i stručna opremljenost, prioriteti u samim planovima i programima i sl. ${ }^{6}$

Takođe, UNESCO-ov Međunarodni institut za visoko obrazovanje u Latinskoj Americi i na Karibima (eng. IESALC), fokusirajući se upravo na svoj primarni delokrug, u izveštaju o uticaju pandemije na oblast visokog obrazovanja u Latinskoj Americi i na Karibima, ali uz napomenu da se nalazi, svakako, mogu primeniti i na druge delove sveta, ukazuje da je neophodno da učimo na greškama koje smo pravili, razumemo pedagoške implikacije do kojih je situacija izmenjenog obrazovanja dovela, a koje ne smeju biti zanemarene ni u narednom periodu, kao i da delimo iskustva, aktivnije se posvetimo međunarodnoj saradnji, ukažemo na potrebu uniformnih, sistematskih rešenja na višem nivou i sl. ${ }^{7}$

Imajući u vidu nepredvidive osobenosti pandemije kojima svakodnevno svedočimo - preporuke Evropske komisije i za predstojeću školsku (akademsku) godinu oslanjaju se na virtuelno okruženje, odnosno na tzv. mešano/ kombinovano (eng. blended) učenje, u cilju očuvanja ne samo obrazovne, no i društvene uloge koju škola, tj. obrazovne institucije imaju u svojoj podlozi. ${ }^{8}$

\footnotetext{
${ }^{3}$ https://unesdoc.unesco.org/ark:/48223/pf0000373348

4 https://ec.europa.eu/education/news/public-consultation-new-digital-education-action-plan en

${ }^{5}$ http://www.iesalc.unesco.org/wp-content/uploads/2020/04/COVID-19-Education-Issue-Note-2.4Planning-1.pdf

${ }^{6}$ https://read.oecd-ilibrary.org/view/?ref=126 126988-t63lxosohs\&title=A-framework-to-guide-aneducation-response-to-the-Covid-19-Pandemic-of-2020

7 http://www.iesalc.unesco.org/en/wp-content/uploads/2020/04/COVID-19-EN-090420-2.pdf

8 https://www.schooleducationgateway.eu/downloads/Blended $\% 20$ learning $\% 20$ in $\% 20$ school $\% 20$ education European\%20Commission June\%202020.pdf
} 


\subsection{Status digitalizovane nastave stranog jezika}

Premda je interakcija neodvojivi činilac uspešnog nastavnog procesa, čini se da je uvreženo mišljenje da nastava jezika zahteva posebnu vrstu interakcije. Kako jezik kojim govorimo oblikuje našu stvarnost na svojevrstan način, te se, putem jezika, izjašnjavamo o svim (ne-jezičkim) oblastima života, pred nastavnicima jezika uvek se nalaze odgovorni zadaci. Inovacije u obrazovanju, tokom poslednjih decenija, dovele su do sve većeg broja kurseva stranih jezika koji se realizuju u onlajn okruženju. Kraj dvadesetog veka (1997) obeležen je intenzivnim ispitivanjima mogućnosti koje onlajn okruženje pruža kada je u pitanju nastava jezika - te, između ostalog, govori se i o autonomiji koju takva vrsta instrukcije donosi učeniku (Furstenberg, 1997 prema Hampel, 2006, str. 105), a samo deset godina kasnije, 2007. godine, zabeleženo je održavanje onlajn kurseva u 130 zemalja (White, 2003 prema Compton, 2009, str. 73).

Da su digitalne inovacije u nastavi stranog jezika očekivane u procesu praćenja tendencija u obrazovanju u celosti govori i podatak o tome da se tzv. telekolaboracija i oslanjanje na onlajn okruženje u procesu razvoja jezičkih veština posredstvom komunikacije sa izvornim govornicima upotrebljavala još devedesetih godina prošlog veka na univerzitetima širom Evrope (O'Dowd, 2013, str. 54), a upravo model srodan navedenom nalazi se i u podlozi projekta INTENT (eng. Integrating Telecollaborative Networks into Foreign Language Higher Education), jednog od projekata celoživotnog učenja EU, koji je okupio sedam zemalja u cilju podrške razmene jezičkih i kulturoloških osobenosti u onlajn okruženju (Lewis, O’Rourke \& Dooly, 2016, str. 1).

Ne treba, svakako, izgubiti iz vida činjenicu da će dobar, uspešan nastavnik u tradicionalnom okruženju biti jednako uspešan i u onlajn okruženju - odnosno, da s lakoćom može da promeni medijum, bez uticaja na nastavu i njen kvalitet (Davis \& Rose, 2007 prema Compton, 2009, str. 75). Savremena nastava stranog jezika podrazumeva nastavnika koji prevashodno ima pedagoško umeće da uspešno organizuje i realizuje nastavni proces, i da svrsishodno koristi tehnološka sredstava, odnosno da ima sposobnost da primeni pedagoški pristup u onlajn nastavnom okruženju, kao i da razvije sopstveni model nastave u datom okruženju (Stickler \& Hampel, 2015, str. 65).

Tokom poslednje decenije, nezavisno od aktuelne situacije, izazvane virusom Kovid-19, na raznolike načine su usavršavane jezičke veštine uz upotrebu IKT-a, štaviše, čak i model kolaborativnog pisanja moguć je u virtuelnom okruženju (Alexander, 2006, Parker \& Chao, 2007 prema Nykopp, Marttunen \& Erkens, 2019, 
str. 537). Uspeh je ostvariv i kada je u pitanju veština govorenja, u čijoj realizaciji, i pored navedenog - izmenjena živa reč, kako sa nastavnikom, tako i sa ostalim članovima grupe, može da utiče na osećaj stvaranja zajednice (Diaz \& Gonzales, 2017, str. 84).

U ovom trenutku, dok se učenici i nastavnici širom sveta još uvek privikavaju na novonastalo obrazovno okruženje, nastaju radovi koji prenose prve utiske u vezi sa uspehom u realizaciji onlajn nastave. Istražuju se brojni aspekti realizacije nastave u onlajn nastavnom okruženju - stavovi nastavnika engleskog jezika o načinu na koji se realizovala nastava na početku izbijanja pandemije, u Republici Srbiji, krajem školske 2019/2020. godine (Tomović \& Aleksić, 2020; Gavranović \& Prodanović, 2021); mogućnosti i karakteristike testiranja u onlajn nastavnom okruženju (Prodanović \& Gavranović, 2021). Ono što jeste izvesno je neophodnost izmena u ulogama svih činilaca nastavnog procesa (Huang et el. 2020, str. 97), kao i da novo okruženje zahteva delikatan pristup brojnim aspektima, kao što su prilagođavanje nastavnih planova i programa, evaluacija, tzv. prisustvo nastavnika (eng. teacher presence), odnosno na koji način nastavnici ostvaruju interakciju sa učenicima (Rapanta et. al., 2020, str. 22-23).

\section{Metodologija istraživanja}

Ovaj rad se bavi istraživanjem stavova studenata anglistike prema mogućnostima koje onlajn nastava pruža u cilju učenja jezika i razvijanja jezičkih veština i kompetencija. Istraživanje se zasniva na analizi rezultata ankete sprovedene među grupom od 97 ispitanika koju čine studenti od prve do četvrte godine Studijskog programa Anglistika, na Univerzitetu Singidunum u Beogradu. Ispitanici su odabrani shodno cilju ovog istraživanja, budući da su oni tokom redovnih studija bili izloženi raznovrsnim aspektima učenja jezika. Ova pilot studija sprovedena je nakon što su studenti poslednja tri meseca akademske 2019/ 2020. godine nastavu imali u sinhronom onlajn okruženju, realizovanom pomoću platforme Google Hangouts Meet, koje je potpomognuto asinhronom tehnologijom platforme Moodle sa koje su studenti mogli da preuzimaju različite nastavne materijale, obaveštenja i informacije.

Anketiranje je bilo anonimno, i sprovedeno je indirektnim putem, kroz elektronski upitnik sačinjen od 12 pitanja zatvorenog tipa, koji se oslanja na Likertovu skalu procene od 1 do 5, mereći stavove i mišljenja studenata u vezi sa mogućnostima koje onlajn okruženje pruža za razvijanje jezičkih kompetencija i veština. Za svaku tvrdnju studenti su na raspolaganju imali pet ponuđenih kategorija slaganja, od one 
čija je vrednost označena sa 1 i glasi ,uopšte se ne slažem", do kategorije ,u potpunosti se slažem", koja je vrednovana brojem 5 .

Rezultati upitnika predstavljeni su kroz analizu svake pojedinačne tvrdnje, formiranjem skalne vrednosti i uspostavljanjem korelacije na primerima parova kategorijalnih varijabli koje se tiču stavova studenata prema istraživačkom problemu korelacije komunikacije u svakodnevnom onlajn okruženju i učestvovanju u onlajn organizovanom obliku nastavnog procesa s jedne strane, i stavova prema mogućnosti razvijanja jezičkih veština u onlajn okruženju, s druge strane.

$\mathrm{Na}$ osnovu analiziranih odgovora na sve pojedinačne tvrdnje iz upitnika, opisan je stepen učestalosti datih kategorija slaganja u odgovorima ispitanika, a rezultati su potom predstavljeni trakastim grafikonom do $100 \%$. Rezultati na svaki odgovor dati su i kroz skalarnu vrednost koja sumira prosečnu vrednost dobijenu za svako pitanje iz analize. Da bi se utvrdila povezanost između određenih varijabli/ obeležja koja su predmet poređenja, rezultati su prikazani pomoću Pirsonovog koeficijenta korelacije, i dvosmernog testa, jer je cilj bio testirati moguće prisustvo i pozitivne i negativne razlike.

\section{Rezultati istraživanja}

Pitanja na koja su studenti odgovarali u anketi nalaze se u Tabeli 1, a brojevi koji slede odnose se na broj studenata koji se odlučio za datu kategoriju, obeleženu od 1 do 5 shodno vrednosti koju nosi za datu kategoriju, i to , uopšte se ne slažem" 1 , ",ne slažem se" 2, „,nemam mišljenje" 3, ,slažem se" 4, i ,u potpunosti se slažem" 5. Poslednja kolona u tabeli označava prosečnu srednju vrednost $(\mathrm{m})$ za dato pitanje.

\begin{tabular}{|l|l|l|l|l|l|l|l|}
\hline & & 1 & 2 & 3 & 4 & 5 & $m$ \\
\hline Pitanje 1 & $\begin{array}{l}\text { Osećam se opušteno kada učestvujem u } \\
\text { svakodnevnoj onlajn komunikaciji }\end{array}$ & 2 & 4 & 8 & 49 & 34 & 4,1 \\
\hline Pitanje 2 & $\begin{array}{l}\text { Osećam se opušteno kada učestvujem u } \\
\text { komunikaciji tokom onlajn nastave }\end{array}$ & 4 & 10 & 14 & 33 & 36 & 3,9 \\
\hline Pitanje 3 & $\begin{array}{l}\text { Posedujem veštine neophodne za aktivno } \\
\text { učestvovanje u onlajn aktivnostima }\end{array}$ & 0 & 2 & 10 & 35 & 50 & 4,4 \\
\hline Pitanje 4 & $\begin{array}{l}\text { Uglavnom nemam tehničkih problema } \\
\text { tokom onlajn nastave }\end{array}$ & 4 & 19 & 21 & 41 & 12 & 3,4 \\
\hline Pitanje 5 & $\begin{array}{l}\text { Onlajn aktivnosti mogu da poboljšaju moje } \\
\text { veštine čitanja }\end{array}$ & 4 & 10 & 32 & 31 & 20 & 3,5 \\
\hline
\end{tabular}


Prodanović, M. \& V. Gavranović: Razvijanje jezičkih veština u onlajn nastavnom okruženju nastalom... 220 Komunikacija i kultura online, Godina XII, broj 12, 2021.

\begin{tabular}{|l|l|l|l|l|l|l|l|}
\hline Pitanje 6 & $\begin{array}{l}\text { Onlajn aktivnosti mogu da poboljšaju moje } \\
\text { veštine slušanja }\end{array}$ & 3 & 10 & 15 & 34 & 25 \\
\hline Pitanje 7 & $\begin{array}{l}\text { Onlajn aktivnosti mogu da poboljšaju moje } \\
\text { veštine pisanja }\end{array}$ & 9 & 11 & 28 & 32 & 16 & 3,3 \\
\hline Pitanje 8 & $\begin{array}{l}\text { Onlajn aktivnosti mogu da poboljšaju moje } \\
\text { veštine govorenja }\end{array}$ & 4 & 6 & 18 & 39 & 30 & 3,8 \\
\hline Pitanje 9 & $\begin{array}{l}\text { Osećam se opuštenije kada učestvujem u } \\
\text { aktivnostima u onlajn nego u } \\
\text { tradicionalnom okruženju }\end{array}$ & 19 & 13 & 26 & 19 & 20 & 3,1 \\
\hline $\begin{array}{l}\text { Pitanje } \\
10\end{array}$ & $\begin{array}{l}\text { U onlajn okruženju najviše mi nedostaje } \\
\text { interakcija sa kolegama i nastavnicima }\end{array}$ & 1 & 9 & 30 & 29 & 28 & 4,1 \\
\hline $\begin{array}{l}\text { Pitanje } \\
11\end{array}$ & $\begin{array}{l}\text { U onlajn nastavi mi se dopada autonomija } \\
\text { u učenju koju ranije nikada nisam imao }\end{array}$ & 7 & 8 & 26 & 33 & 23 & 3,6 \\
\hline $\begin{array}{l}\text { Pitanje } \\
12\end{array}$ & $\begin{array}{l}\text { Onlajn nastava zahteva veći stepen } \\
\text { motivacije kod studenata za } \\
\text { učestvovanjem u aktivnostima }\end{array}$ & 10 & 9 & 21 & 37 & 20 & 3,5 \\
\hline
\end{tabular}

Tabela 1. Pitanja iz upitnika sa brojem ispitanika i srednjom vrednošću za svaki odgovor

Odgovori na pitanja mogu se predstaviti i grafički, pomoću trakastog grafikona naslaganog do 100, koji prikazuje odnos skalnih vrednosti za svako pojedinačno pitanje iz upitnika, izražen u procentima.

\section{Grafikon 1. Odnos skalnih vrednosti za svako pitanje}

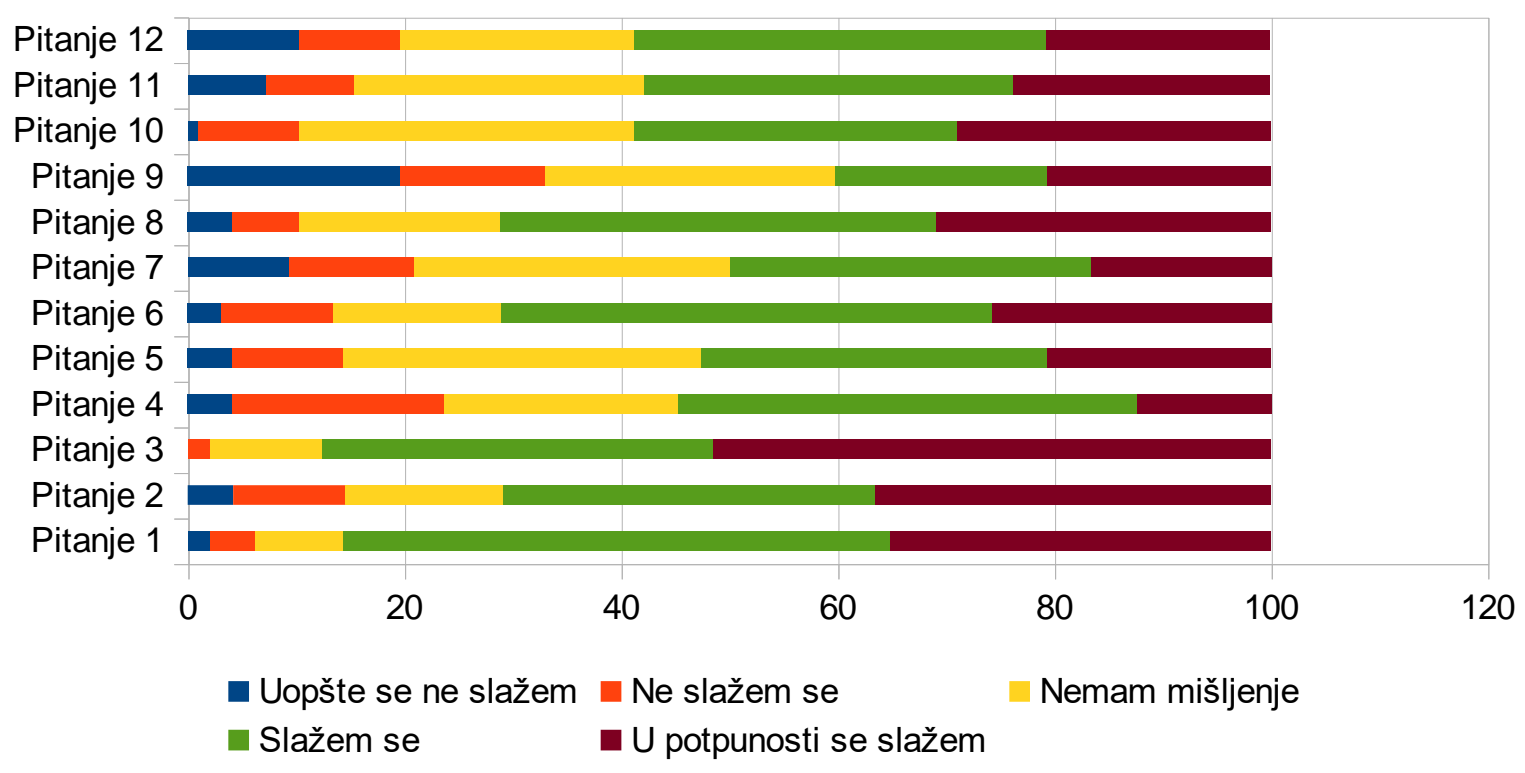


Deskriptivna statistika prva dva pitanja koja se odnose na afektivni stav studenata prema komunikaciji u onlajn okruženju, bilo da je ono neformalno, kao što je u svakodnevnoj komunikaciji, ili je u pitanju formalni kontekst odvijanja nastave, može se izraziti na sledeći način:

- srednja vrednost rezultata za Pitanje 1 iznosi 4,1 dok je standardna devijacija vrednosti 0,87 .

- srednja vrednost rezultata za Pitanje 2 iznosi 3,9, dok je standardna devijacija vrednosti 1,15 .

Korelacija između stavova studenata prema onlajn komunikaciji uopšte i komunikaciji u onlajn nastavnom okruženju data je u Tabeli 2.

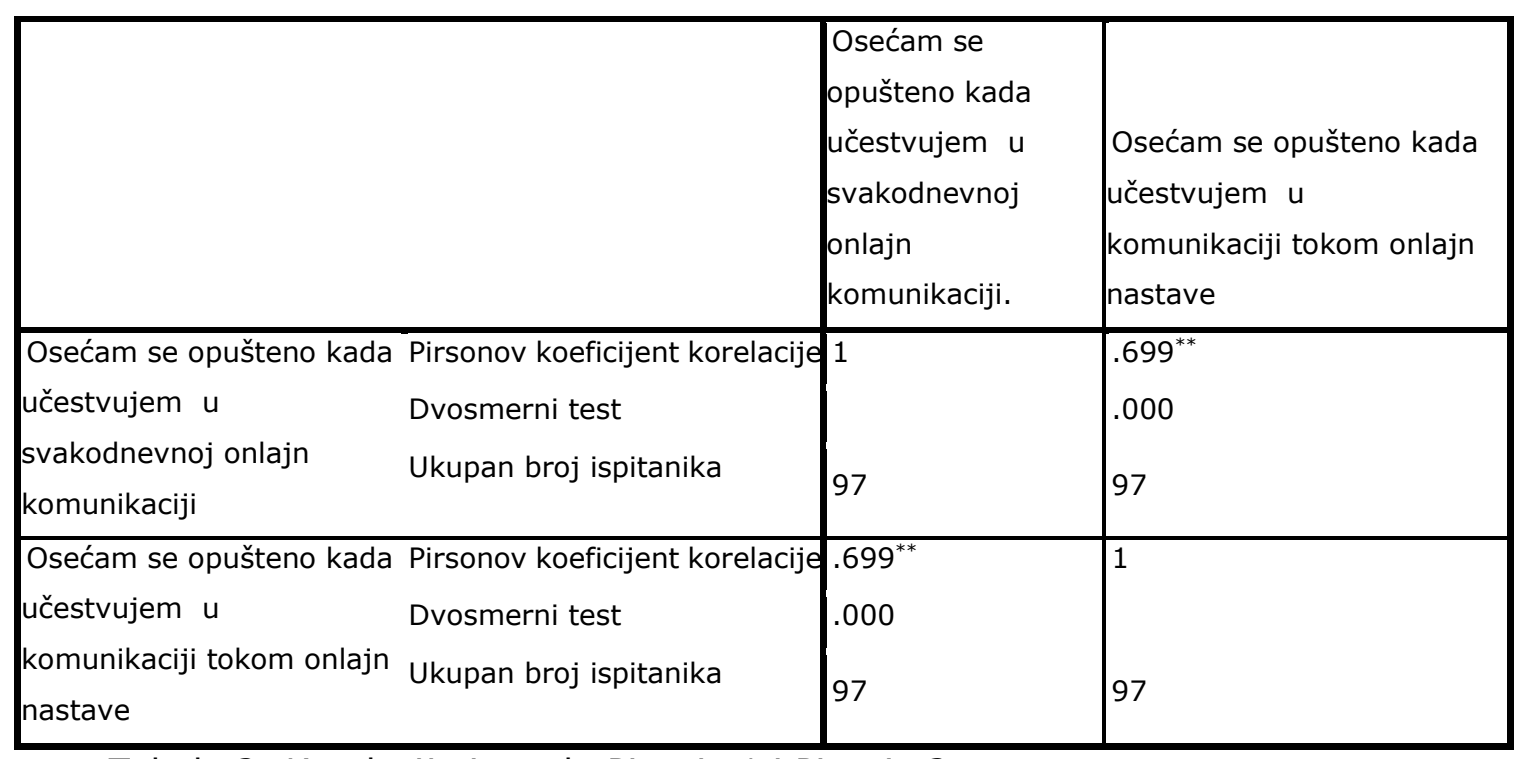

Tabela 2: Korelacija između Pitanja 1 i Pitanja 2

Deskriptivna statistika Pitanja 5-8, koja se odnose na stav studenata prema mogućnostima razvijanju receptivnih i produktivnih jezičkih veština u onlajn nastavnom okruženju može se izraziti na sledeći način:

- srednja vrednost rezultata za Pitanje 5 iznosi 3., dok je standardna devijacija vrednosti 1,03 .

- srednja vrednost rezultata za Pitanje 6 iznosi 3,8, dok je standardna devijacija vrednosti 1,01 .

- srednja vrednost rezultata za Pitanje 7 iznosi 3,3, dok je standardna devijacija vrednosti 1,3 . 
Prodanović, M. \& V. Gavranović: Razvijanje jezičkih veština u onlajn nastavnom okruženju nastalom... 222 Komunikacija i kultura online, Godina XII, broj 12, 2021.

- srednja vrednost rezultata za Pitanje 8 iznosi 3,8, dok je standardna devijacija vrednosti 1,004 .

Korelacija između stavova studenata prema razvijanju jezičkih veština u onlajn nastavnom okruženju data je u Tabeli 3.

\begin{tabular}{|c|c|c|c|c|c|}
\hline & & $\begin{array}{l}\text { Onlajn } \\
\text { aktivnosti } \\
\text { mogu da } \\
\text { poboljšaju } \\
\text { moje veštine } \\
\text { čitanja }\end{array}$ & $\begin{array}{l}\text { Onlajn } \\
\text { aktivnosti } \\
\text { mogu da } \\
\text { poboljšaju } \\
\text { moje veštine } \\
\text { slušanja }\end{array}$ & $\begin{array}{l}\text { Onlajn } \\
\text { aktivnosti } \\
\text { mogu da } \\
\text { poboljšaju } \\
\text { moje veštine } \\
\text { pisanja }\end{array}$ & $\begin{array}{l}\text { Onlajn } \\
\text { aktivnosti } \\
\text { mogu da } \\
\text { poboljšaju } \\
\text { moje veštine } \\
\text { govorenja }\end{array}$ \\
\hline $\begin{array}{l}\text { Onlajn aktivnosti mogu da } \\
\text { poboljšaju moje veštine čitanja }\end{array}$ & $\begin{array}{l}\text { Pirsonov } \\
\text { koeficijent } \\
\text { korelacije } \\
\text { Dvosmerni test } \\
\text { Ukupan broj } \\
\text { ispitanika }\end{array}$ & 97 & $\begin{array}{l}.700^{* *} \\
.000 \\
97\end{array}$ & $\begin{array}{l}.752^{* *} \\
.000 \\
97\end{array}$ & $\begin{array}{l}.578^{* *} \\
.000 \\
97\end{array}$ \\
\hline $\begin{array}{l}\text { Onlajn aktivnosti mogu da } \\
\text { poboljšaju moje veštine } \\
\text { slušanja }\end{array}$ & $\begin{array}{l}\text { Pirsonov } \\
\text { koeficijent } \\
\text { korelacije } \\
\text { Dvosmerni test } \\
\text { Ukupan broj } \\
\text { ispitanika }\end{array}$ & $\begin{array}{l}.700^{* *} \\
.000 \\
97\end{array}$ & 97 & $\begin{array}{l}.718^{* *} \\
.000 \\
97\end{array}$ & $\begin{array}{l}.774^{* *} \\
.000 \\
97\end{array}$ \\
\hline $\begin{array}{l}\text { Onlajn aktivnosti mogu da } \\
\text { poboljšaju moje veštine pisanja }\end{array}$ & $\begin{array}{l}\text { Pirsonov } \\
\text { koeficijent } \\
\text { korelacije } \\
\text { Dvosmerni test } \\
\text { Ukupan broj } \\
\text { ispitanika }\end{array}$ & $\begin{array}{l}.752^{* *} \\
.000 \\
97\end{array}$ & $\begin{array}{l}.718^{* *} \\
.000 \\
79\end{array}$ & 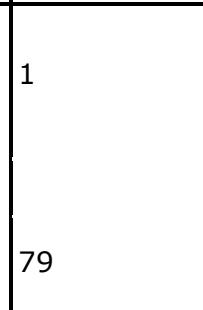 & $\begin{array}{l}.557^{* *} \\
.000 \\
79\end{array}$ \\
\hline $\begin{array}{l}\text { Onlajn aktivnosti mogu da } \\
\text { poboljšaju moje veštine } \\
\text { govorenja }\end{array}$ & $\begin{array}{l}\text { Pirsonov } \\
\text { koeficijent } \\
\text { korelacije } \\
\text { Dvosmerni test } \\
\text { Ukupan broj } \\
\text { ispitanika }\end{array}$ & $\begin{array}{l}.578^{* *} \\
.000 \\
97\end{array}$ & $\begin{array}{l}.774^{* *} \\
.000 \\
97\end{array}$ & $\begin{array}{l}.557^{* *} \\
.000 \\
97\end{array}$ & $\begin{array}{l}1 \\
\\
97\end{array}$ \\
\hline
\end{tabular}

Tabela 3: Koeficijent korelacije između pitanja koja se odnose na jezičke veštine 


\section{Analiza rezultata i diskusija}

Odgovori ispitanika na pitanja koja se odnose na njihov emocionalni stav prema onlajn komunikaciji ukazuju da je on izrazito pozitivan i da je veoma mali procenat, svega $6 \%$ odgovorio da se ne oseća prijatno u ovom formatu komunikacije. Takođe je izrazito visok procenat pozitivne emocije vezane za komunikaciju u onlajn nastavnom okruženju, što predstavlja važan pokazatelj da današnji studenti onlajn okruženje doživljavaju kao prijatno za odvijanje komunikacije ne samo u neformalnom kontekstu, već i izrazito formalnom kao što je akademsko okuženje. Ovaj rezultat takođe potvrđuje da su studenti 21. veka "digitalni starosedeoci" i da digitalno okruženje doživljavaju kao prirodno, u kojem ,govore izvornim jezikom tehnologije" (Dingli \& Seychell, 2015, str. 15). Prilikom analize rezultata dobijenih na prva dva pitanja, izraženih Pirsonovim koeficijentom korelacije, pokazalo se da je stepen zavisnosti između pozitivnog stava studenata prema svakodnevnoj, neformalnoj onlajn komunikaciji i komunikaciji u onlajn nastavnom okruženju visok, odnosno da postoji statistička značajnost prilikom analize ove povezanosti, i da je koeficijent korelacije 0,7 .

U vezi sa rezultatima za prva dva pitanja su i odgovori na pitanja u kojoj meri studenti poseduju veštine potrebne za obavljanje uspešne komunikacije tokom onlajn nastave, i srednja vrednost ukazuje da je ovo pitanje koje ima najvišu srednju vrednost - na dato pitanju nijedan student nije odgovorio sa "uopšte se ne slažem", a samo dvoje je dalo odgovor ,"ne slažem se", što ukazuje na visok stepen samouverenosti prisutne kod studenata, ali i jedne od osnovih mana Likertove skale, a to je pitanje iskrenosti ispitanika. $U$ vezi sa kritičkim odnosom prema vlastitom snalaženju u onlajn okruženju je i pitanje koje se odnosi na postojanje tehničkih problema tokom onlajn nastave, gde je srednja vrednost značajno veća. Međutim, treba imati u vidu da dobre veštine podrazumevaju i sposobnost efikasnog otklanjanja prepreka za onlajn komunikaciju, posebno kada se one ponavljaju, na šta ukazuje pridev ,uglavnom".

Analiza rezultata stavova studenata prema mogućnosti razvijanja jezičkih veština u onlajn okruženju pokazuje da većina ispitanika ima pozitivan stav, i da se odabrane vrednosti nalaze između 3,3 i 3,8 vrednosti podeoka na mernoj skali, čija je vrednost od 1-5. Ipak, u odnosu na rezultate pitanja koji se odnose na pozitivan afektivni stav prema onlajn nastavi i komunikaciji, vrednosti su niže, i to pokazuje da su ovo elementi nastave koji se mogu poboljšati. Pored promena koje se odnose na redefinisanje pedagoških principa i praksi u novom digitalnom okruženju, nastavnici jezika imaju 
dodatne izazove kada su u pitanju tehnike i metode podučavanja jezičkih veština u onlajn okruženju. Ovo istraživanje je pokazalo da studenti smatraju da onlajn nastava pruža veće mogućnosti za razvijanje jezičkih veština slušanja i govorenja u odnosu na čitanje i pisanje, odnosno da je srednja vrednost za prve dve jednaka, i iznosi 3,8, dok je srednja vrednost rezultata statova studenata prema mogućnostima razvijanja veština čitanja i pisanja (nešto) manja, i iznosi 3,5 i 3,3, tim redom. Dobijeni rezultati daju novu vrednost podučavanju jezičkih veština, koje se, u tradicionalnom nastavnom okruženju dele na receptivne i produktivne, i kao takve definišu u tim kategorijama. Međutim, ovi rezultati pokazuju da postoji veći koeficijent korelacije između jedne receptivne veštine (veštine slušanja), i jedne produktivne veštine (veštine govorenja) i onlajn okruženja u odnosu na korelaciju preostale dve veštine sa onlajn okruženjem, što navodi na dodatno promišljanje o načinu podučavanja jezičkih veština budući da su ,'digitalni starosedeoci veoma sofisticirani kada biraju način na koji dolaze do informacija" (Palfrey \& Gasser, 2008, str. 343).

Primećeno je da se institucije u oblasti visokog obrazovanja ređe odlučuju na upotrebu onlajn modela učenja i nastave, te da se, kao osnovne prepreke, navode nedovoljan nivo interakcije, kao i nedostatak stručne obuke (Allen et al., 2016). Pored navedenog, kroz prizmu nastave stranog (u ovom slučaju - engleskog) jezika, Pu (2020) primećuje da se nastavnici susreću i sa pitanjima prilagođenosti nastavnih planova i programa, nedoumicama u procesu evaluacije znanja, internet vezom tokom realizacije aktivnosti, što, zajedno, dovodi do ,,nesigurnosti nastavnika u vezi sa tim da li je onlajn komunikacija delotvorna" (str. 347). Iako gore navedeni rezultati ukazuju na visok stepen pozitivnog odnosa prema onlajn okruženju, odgovori na pitanja koja se tiču poređenja onlajn i tradicionalnog nastavnog okruženja pokazuju da se studenti, u velikom procentu (oko jedne trećine opredelilo se za negativan stav, što predstavlja najveći ukupan negativan stav u odnosu na ostala pitanja) i dalje osećaju opuštenije kada učestvuju u aktivnostima koje se realizuju u tradicionalnom okruženju, tako da je ovo pitanje sa odgovorima koji su u vrhu sa najmanjom srednjom vrednošću u odnosu na sve ostale, koja iznosi oko 3,1. Studenti su visokom srednjom vrednošću, 4,1 ocenili da im nedostaje interakcija sa kolegama i nastavnicima. Ovaj podatak upravo ukazuje na potrebu da se usklade tehnike i metode podučavanja u onlajn okruženju sa već postojećim pozitivnim afektivnim stavom studenata prema ovoj vrsti nastavnog konteksta. U tome umnogome mogu doprineti saznanja iz teorije kolaborativnog onlajn učenja, koja pored standardnih teorija koje pripadaju dvadesetom veku, kao što su bihejvioristička, kognitivna i konstruktivistička, daje 
značajan doprinos u sferi obrazovanja u 21. veku (Li, 2017, str. 8). Baveći se pitanjem digitalnog u obrazovanju, Evropska komisija je objavila analitički izveštaj o uticaju tehnologije na empatiju učenika, kao i na držanje pažnje (Flecha et al., 2020). Izveštaj ukazuje na to da kontekst, zajedno sa odabirom uživanog sadržaja, nesumnjivo, utiče na empatiju, te na vremenski period tokom kojeg sadržaj drži pažnju; empatija se više primećuje tokom aktivnosti koje uključuju društvenu interakciju; takođe je potvrđena važnost odabira upotrebljenog sadržaja budući da sadržaji, svojim osobinama, mogu da izazovu agresiju ili diskriminaciju, da umanje stepen empatije, ali i da uruše društvenu interakciju.

Rezultati koji se odnose na stav učenika prema autonomiji koju onlajn nastava pruža pokazuje pozitivan afektivni stav, s prosečnom ocenom 3,6, što je takođe važan pokazatelj za pripremu u realizaciju nastave u kojoj studentima treba dati veći stepen samostalnosti u učenju, pri čemu se podstiče i preuzimanje odgovornosti nad procesom vlastitog učenja. S tim u vezi su i rezultati na poslednje pitanje koje se tiče motivacije, i prosečna vrednost od 3,5 ukazuje da je kod studenata razvijena svest o važnosti motivacije za učestvovanjem u aktivnostima u onlajn nastavi, pokazatelj koji takođe treba uzeti u obzir prilikom planiranja i organizovanja nastave u onlajn okruženju.

\section{Zaključak}

Iznenadne promene u obrazovnim sistemima, nastale usled izbijanja pandemije izazvane širenjem virusa Kovid-19, pre svega su se odigrale u okruženju u kojem se nastava odvijala - od isključivo tradicionalnog načina realizovanja nastave na svim nivoima formalnog obrazovanja, u proleće 2020. godine nastava se preko noći premestila u onlajn okruženje, za koje ni nastavnici ni učenici nisu bili unapred pripremljeni. Na ovu novonastalu situaciju obrazovne institucije su odgovorile na različite načine, i sa različitim stepenom posvećenosti i uspešnosti, ali ono što su Ujedinjene nacije istakle kao imperativ jeste da je neophodna hitna reakcija svih da bi se sprečilo da kriza u obrazovanju preraste u katastrofu ${ }^{9}$.

$\mathrm{U}$ ovom radu izneto je istraživanje sprovedeno među studentima anglistike koji su tri poslednja meseca akademske 2019/ 2020. godine nastavu imali isključivo u onlajn sinhronom nastavnom okruženju, potpomognuto asinhronom platformom Moodle na kojoj su postavljani nastavni materijali i relevantna obaveštenja. Putem

${ }^{9}$ https://www.un.org/development/desa/dspd/wpcontent/uploads/sites/22/2020/08/sg policy brief covid-19 and education august 2020.pdf. 
ankete, studenti su izneli svoje afektivne stavove prema onlajn nastavi uopšte, kao i prema mogućnostima razvijanja jezičkih veština u takvom nastavnom kontekstu.

Rezultati ove studije pokazali su da su za ,digitalne starosedeoce" digitalne tehnologije sastavni deo života, da prema njima imaju pozitivan stav, i da, za razliku od digitalnih imigranata, ne predstavljaju novinu niti inovaciju - za njih se upotreba tehnologije podrazumeva (Dingly \& Seychell, 2015, str. 8). Studenti su pokazali izrazito pozitivan stav ne samo prema svakodnevnoj komunikaciji u onlajn okruženju, što se moglo i očekivati od "digitalnih starosedelaca" već i prema komunikaciji u kontekstu onlajn nastave. Visok stepen korelacije između ove dve vrste komunikacije ukazuje na pozitivan stav studenata koji treba uzeti u obzir kao mogućnost i prednost prilikom planiranja i realizovanja nastave. Rezultati ove studije takođe ukazuju na važnost redefinisanja podučavanja jezičkih veština, i uzimanja u obzir svih mogućnosti i aspekata koje digitalne tehnologije pružaju u cilju osnaživanja jezičkih veština i kompetencija. Visok stepen korelacije koji postoji između stavova studenta prema mogućnosti razvijanja veštine slušanja i govorenja s jedne strane, i veštine pisanja i čitanja s druge, ukazuje na to da digitalno okruženje pruža specifične karakteristike koje mogu baciti novo svetlo na podučavanje receptivnih i produktivnih veština.

Iako je stav studenata prema onlajn nastavnom okruženju pozitivan, studenti su ipak dali prednost tradicionalnom okruženju jer su iskazali da im nedostaje interakcija sa kolegama i nastavnicima u fizičkoj učionici. Iskustvo koje je donela onlajn nastava ukazuje na potrebu da se kritički osvrnemo na različite aspekte podučavanja jezika i da ih redefinišemo shodno brojnim društvenim i kulturnim promenama, s ciljem da se nastava jezika učini kvalitetnijom i svrsishodnijom potrebama i interesovanjima studenata 21. veka, bez obzira u kojem kontekstu se ono odvijalo.

Stav ispitanika je važan korak u planiranju nastavnog procesa i kreiranju aktivnosti koje će doprineti boljim ishodima učenja jezika, ali u cilju formiranja verodostojnije slike o mogućnostima razvijanja jezičkih veština u onlajn okruženju potrebno je sprovesti istraživanja koja se tiču i samih tehnika podučavanja, kao i ishoda učenja merenih objektivnim testovima. Prostor za istraživanje koji je iznenada otvoren izbijanjem pandemije ima potencijal da doprinese kvalitetnijem teorijskom okviru koji će pružiti odgovore na višeslojnost prirode podučavanja jezika, koju savremene društvene okolnosti čine još kompleksnijom. 


\section{Literatura}

Allen, I. E., Seaman, J., Poulin, R., \& Straut, T. T. (2016). Online report card: Tracking online education in the United States. Babson Park: Babson Survey Research Group. $\quad$ Retrieved from http://onlinelearningsurvey.com/reports/onlinereportcard.pdf.

Compton, L. K. (2009). Preparing language teachers to teach language online: a look at skills, roles, and responsibilities. Computer Assisted Language Learning, 22(1), 73-99. DOI:10.1080/09588220802613831

Díaz, H., L. E., \& González Miy, D. (2017). Developing the oral skill in online English courses framed by the community of inquiry. PROFILE Issues in Teachers' $\begin{array}{lll}\text { Professional Development, 19(1), 73-88. } & \text {. }\end{array}$ http://dx.doi.org/10.15446/profile.v19n1.55957

Dingli, A., \& Seychell, D. (2015). The New Digital Natives. Cutting the Cord. New York: Basic Books.

Flecha, R., Pulido, C., Villarejo, B., Racionero, S., Redondo, G., Torras, E. (2020). 'The effects of technology use on children's empathy and attention capacity', NESET report. Luxembourg: Publications Office of the European Union. Doi: $10.2766 / 947826$.

Gavranović, V. \& Prodanović, M. (2021). ESP Teachers' Perspectives on the Online Teaching Environment Imposed in the COVID-19 Era: A Case Study. The New Educational Review, 64, (2), 188-198. doi:10.15804/tner.2021.64.2.15

Hampel, R. (2006). Rethinking task design for the digital age: A framework for language teaching and learning in a synchronous online environment. ReCALL, 18(1), 105-121. http://dx.doi.org/doi:10.1017/S0958344006000711

Huang, R.H., Liu, D.J., Guo, J., Yang, J.F., Zhao, J.H., Wei, X.F., Knyazeva, S., Li, M., Zhuang, R.X., Looi, C.K., \& Chang, T.W. (2020). Guidance on Flexible Learning during Campus Closures: Ensuring course quality of higher education in COVID19 outbreak. Beijing: Smart Learning Institute of Beijing Normal University.

Lewis, T. O'Rourke. B. \& Dooly, M. (2016). Innovation in language learning and teaching - Online Intercultural Exchange. Innovation in Language Learning and Teaching, 10(1), 1-6. DOI: 10.1080/17501229.2015.1133541

Li, L. (2017). New Technologies and Language Learning. London: Macmillan Education Palgrave. 
Nykopp, M., Marttunen, M. \& Erkens, G. (2019). Coordinating collaborative writing in an online environment. Journal of Computing in Higher Education, 31, 536-556. https://doi.org/10.1007/s12528-018-9203-3

O'Dowd, R. (2013). The INTENT Project: Integrating Telecollaborative Networks into Foreign Language Higher Education. The EuroCALL Review, 21 (1), 54-59. doi:https://doi.org/10.4995/eurocall.2013.10162.

Palfrey, J., \& Gasser, U. (2008). Born Digital. Understanding the First Generation of Digital Natives. New York: Springer.

Prodanović, M., Gavranović, V. (2021). Assessing Grammar in Online Environment: A Comparison between High and Low Stakes Test Performance. Društvene $i$ humanističke studije, 6, 265-278. doi: https://doi.org/10.51558/24903647.2021.6.3.265

$\mathrm{Pu}, \mathrm{H}$. (2020). Implementing online ELT in the time of crisis: ordeal or opportunity? ELT Journal, 74 (3), 345-348. https://doi.org/10.1093/elt/ccaa030 https://ec.europa.eu/education/news/public-consultation-new-digitaleducation-action-plan en

Rapanta, C., Botturi, L., Goodyear, P., Guardia, L. \& Koole, M. (2020). Online University Teaching During and After the Covid-19 Crisis: Refocusing Teacher Presence and Learning Activity. Postdigital Science and Education, 1-23. https://doi.org/10.1007/s42438-020-00155-y

Stickler U., Hampel R. (2015). Transforming Teaching: New Skills for Online Language Learning Spaces. In Hampel R., Stickler U. (Eds.), Developing Online Language Teaching. New Language Learning and Teaching Environments (pp. 63-77). London: Palgrave Macmillan. https://doi.org/10.1057/9781137412263 5

Tomović, N., Aleksić, M. (2020). Online nastava engleskog jezika u Srbiji tokom pandemije virusa Covid-19. Komunikacija i kultura $<e m>$ online</em>, [S.I.], $11(11), 241-250$.

\section{Izvori}

Policy Brief: Education during COVID-19 and beyond. United Nations, 2020, https://www.un.org/development/desa/dspd/wpcontent/uploads/sites/22/2020/08/sg policy brief covid19 and education august 2020.pdf. https://www.schooleducationgateway.eu/downloads/Blended $\% 20$ learning $\% 20 \mathrm{in} \% 20$ school\%20education European\%20Commission June\%202020.pdf 
https://unesdoc.unesco.org/ark:/48223/pf0000373348

https://read.oecd-ilibrary.org/view/?ref=126 126988-t63lxosohs\&title=A-

framework-to-guide-an-education-response-to-the-Covid-19-Pandemic-of-2020

http://www.iesalc.unesco.org/en/wp-content/uploads/2020/04/COVID-19-EN-

090420-2.pdf

http://www.iesalc.unesco.org/wp-content/uploads/2020/04/COVID-19-Education-

Issue-Note-2.4-Planning-1.pdf

\section{Summary}

\section{DEVELOPING LANGUAGE SKILLS IN AN ONLINE LEARNING ENVIRONMENT CREATED AS A RESULT OF THE COVID-19 OUTBREAK - POSSIBILITIES AND LIMITATIONS}

The impact of the COVID-19 outbreak on everyday life has been enormous, and educational institutions, policy makers, teachers and students faced challenges imposed on them overnight as a result of switching exclusively to an online teaching context. Teaching habits, approaches, methods and materials had to be adapted to the online context, and the educational systems across the whole world responded to a newly created situation in different ways, and with varying degrees of success.

This paper reports on a pilot study conducted among a group of 97 students majoring in English, who, for the last three months of the academic year 2019/2020, experienced synchronous online learning, supported by the asynchronous Moodle platform used for material distibution. The survey used for the study is based on a five-point Likert scale which examines students' attitudes towards different aspects of language teaching and learning in an online environment, and the variables are measured by the Pearson correlation coefficient.

The aim of this study is to investigate the respondents' attitudes towards online language learning environment and the possibilities it provides for the development of all language skills and competencies. It also focuses on the analysis of the correlation between the answers pertaining to students' affective attitudes towards everyday online communication and communication in an online language teaching and learning context, as well as the correlation established for students' attitudes towards the possibilities to develop both receptive and productive language skills.

The results of the research are represented through both a qualitative narrative and the comparison of variables, and quantitative, statistic data describing every single question and the established correlations. The obtained results point to a high degree of positive attitide towards all aspects of language teaching in an online environment, and also to the degree of correlations existing between the attitudes towards the possibility of developing all language skills.

The results of the study also point to the importance of redefining the techniques, methods and materials used for teaching language skills, while taking into consideration all possibilities and aspects that digital technologies offer, with the aim of enhancing students' language skills and competencies. The high correlation established between the variables of respondents' attitudes towards the possibilites to develop language skills illuminates the potential of online teaching and learning environment, which needs to be reexamined and thorougly exploited in order to meet the needs of the the 21st century language learners successfully and effectively, regardless of the context wherein it is realised. The experience brough along by the online teaching imposed by the outbreak of COVID-19 opens many questions and casts a new light on different aspects of language teaching.

Key words: online learning, language skills development, Anglistics students' attitudes. 